\title{
Trypsin-amplified Aerolysin Nanopore Amplified Sandwich Assay for Attomolar Nucleic Acid and Single Bacteria Detection
}

Fengge Songa ${ }^{a}$ Ruijie Deng ${ }^{b, d}$, Hong Liua , Aimin Wanga , Chuanxin Maa , Yangdao Weia, Xiaojian Cuic, Yi Wana, ${ }^{a}$, Jinghong $\mathrm{Li}^{\mathrm{b}^{*}}$

${ }^{a}$ Key Laboratory of Tropical Biological Resources of Ministry of Education, School of Life and Pharmaceutical Sciences, Marine College, State Key Laboratory of Marine Resource Utilization in South China Sea, Hainan University, Haikou 570228, China.

${ }^{b}$ Department of Chemistry, Key Laboratory of Bioorganic Phosphorus Chemistry \& Chemical Biology, Tsinghua University, Beijing 100084, China.

`National Marine Data \& Information Service, Tianjin 300170, China.

${ }^{d}$ College of Light Industry, Textile and Food Engineering and Healthy Food Evaluation Research Centre, Sichuan University, Chengdu 610065, China

Email: 993602@hainu.edu.cn (Dr. Yi Wan) and jhli@mail.tsinghua.edu.cn (Prof. Jinghong Li) 


\section{Table of Contents}

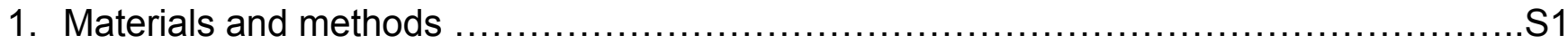

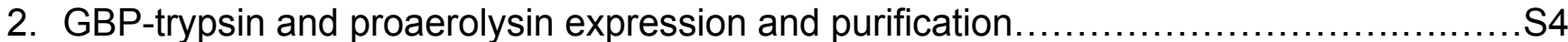

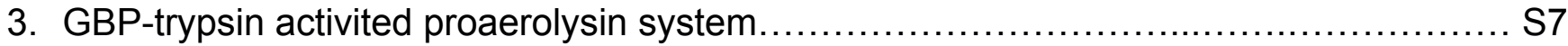

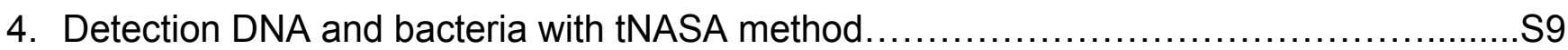

5. Detection bacteria and clinic diagnostic with qPCR method............................... 10

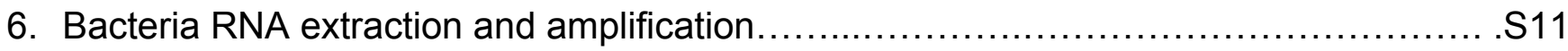

7. Detection bacteria and clinic diagnostic with qPCR and culture method. ................... 12 


\section{Experimental Procedures}

\section{Materials and methods}

\subsection{Proaerolysin expression and purification}

The cloning vector (proaerolysin-pET22b $(+)$ ) was provided from NovoPro Bioscience Inc. and confirmed by Sangon Biotech. Transformed Escherichia coli strain transtta DE3 (TransGen Biotech) using an expression vector with His6 tag was incubated at $37^{\circ} \mathrm{C}$ in LB medium supplemented with 50 $\mu \mathrm{g} \mathrm{mL}^{-1}$ ampicillin with shaking at $150 \mathrm{rpm}$ until the early stationary phase.(1) To obtain the protein of interest, the culture with isopropyl- $\beta$-d-thiogalactopyranoside (IPTG, $0.5 \mathrm{mM}$ ) was further shaked for 18 $\mathrm{h}$ at $25{ }^{\circ} \mathrm{C}$. Bacterial cells were obtained by centrifugation at $5000 \mathrm{~g}$ for $10 \mathrm{~min}$ at $4{ }^{\circ} \mathrm{C}$, and then obstructed using a sonicator. The debris was dismantled by centrifugation at $12,000 \mathrm{~g}$ for $30 \mathrm{~min}$ at $4^{\circ} \mathrm{C}$, and the supernatant was added onto Bio-Scale Mini Nuvia IMAC Ni-Charged (Bio-Rad Laborataries, Inc). Fractions containing proaerolysin were concentrated and then further purified on Enrich SEC 650 High-Resolution Size Exclusion Columns (Bio-Rad Laborataries, Inc). Proaerolysin was confirmed by SDS-PAGE, western blots and Qubit® Protein Assay Kits (Lot: 1790704, Molecular Probes by Life Technologies).

\subsection{Bacteria culture and nucleic acid (DNA and RNA) extraction}

All bacteria were provided from the China Center of Industrial Culture Collection (CICC). For gramnegative bacteria (Escherichia coli, Eberthella typhi, Vibrio parahaemolyticus, Pseudomonas aeruginosa, Klebsiella pneumonia and Proteus mirabilis), bacteria were first centrifuged (6,000 r.p.m., $10 \mathrm{~min}$ ), and pellets were mixed with lysozyme, then lysed using BRK Lysis Buffer (Bacterial RNA kit, Omega). For gram-positive bacteria (Staphylococcus aureus, Listeria monocytogenes, Streptococcus pyogenes, and Enterococcus faecalis), bacteria were first centrifuged (6,000 r.p.m., $10 \mathrm{~min}$ ), and pellets were mixed with lysozyme with $\sim 200 \mathrm{mg}$ of zirconia beads. The bacterial cells were broken on a tissue cell-destroyer (NewZongKe Viral Disease Control Bio-Tech LTD.) with a small tube adapter for 10 min and then lysed using BRK Lysis Buffer (Bacterial RNA kit, Omega). After solvent extraction of the RNA followed by HiBind® RNA Mini Column and washing, the final RNA yield was detected using NanoDrop Microvolume Spectrophotometers (Thermo Scientific) and agarose gel electrophoresis (DYY-6D, Beijing Liuyi Biotechnology Co. Ltd).

\subsection{Primer and probe design}

The gene sequences of each bacteria (16S rRNA) from NCBI database were screened to gain a target region of interest (50-80 nucleotides in length) for hybridization using MegAlign software (DNASTAR)(2). To detect different genus types for pathogen and virus, both specific probes (detection probe and capture detection with c.a. 20 nucleotides) were used to combine to sequences within the 
target regions of interest. All oligonucleotides used for the primers and probes were provided by Sangon Biotech. Unmodified capture and detection probes were hybridized with target DNA. Each pair of probes were reacted with the RT-PCR product derived from each pathogen (molar ratio of target DNA:capture probe detection probe $=1: 3: 3$ ), incubated in PBS at $37^{\circ} \mathrm{C}$ for $1 \mathrm{~h}$. Probe specificity was performed by polyacrylamide gel electrophoresis.

\subsection{Asymmetric-PCR}

The cDNA from different bacterial RNA from samples were prepared using PrimeScript II 1st Strand cDNA Synthesis Kit (Takara) with thermal cycling conditions of $42{ }^{\circ} \mathrm{C}$ for $60 \mathrm{~min}$, followed by $70{ }^{\circ} \mathrm{C}$ for 5 min. For asymmetric amplification, cDNAs were amplified with Max DNA polymerase and specific primers for bacteria (Table S1). Either the forward or reverse primers were added in excess (relative to the other primer). The following thermal cycling conditions were used: initiation $\left(94^{\circ} \mathrm{C}, 5 \mathrm{~min}\right) ; 35$ cycles of denaturation $\left(94^{\circ} \mathrm{C}, 30 \mathrm{~s}\right)$, annealing $\left(55^{\circ} \mathrm{C}, 30 \mathrm{~s}\right)$, extension $\left(72^{\circ} \mathrm{C}, 30 \mathrm{~s}\right)$; and termination $\left(72^{\circ} \mathrm{C}, 7\right.$ min). The final products were measured by polyacrylamide gel electrophoresis (DYY-6D, Beijing Liuyi Biotechnology Co. Ltd).

\subsection{Quantitative PCR analysis with SYBR Green}

To compare tNASA technique with other accepted approaches, we carried out quantitative PCR on a series of samples. For qPCR, the cDNA derived from bacterial cells were incubated with SYBR Green Master Mix (Eastep® qPCR Master Mix kit, Promega) and specific primers utilized above for PCR. The mixtures were then applied to the QuantStudio 6 Flex (Applied Biosystems, Life Technologies) and thermal cycling was carried out for 35 cycles at $95{ }^{\circ} \mathrm{C}$ for $3 \mathrm{~s}$ followed by $60{ }^{\circ} \mathrm{C}$ for $30 \mathrm{~s}$. Relative amounts of target were calculated based on the $C_{T}$ values.

\section{6 tNASA for Blood samples}

This blood samples were collected according to the principles expressed in the Declaration of Helsinki. These samples were provided friendly from the 187th hospital of Haikou and analysed with the tNASA assay, before being compared to conventional culture using BioLumix $($ Neogen) and qPCR using the QuantStudio 6 Flex. We selected 7 samples corresponding to six patients with suspected infections and one healthy adult's samples as a negative sample. After solvent extraction of the RNA, bacterial detection and identification were measured based on the above-mentioned tNASA experiments. 
Table S1. Sequences of probes and primers for bacterial detection.

\begin{tabular}{|c|c|c|c|c|c|}
\hline type & $\begin{array}{l}\text { Capture } \\
\text { probe }\end{array}$ & $\begin{array}{l}\text { Detection } \\
\text { probe }\end{array}$ & Amplicon & $\begin{array}{l}\text { Forward } \\
\text { primer }\end{array}$ & $\begin{array}{l}\text { Reverse } \\
\text { primer }\end{array}$ \\
\hline $\begin{array}{l}\text { Escherichia } \\
\text { coli }\end{array}$ & $\begin{array}{l}\text { TAACTTTAC } \\
\text { TCCCTTCCT } \\
\text { CAAAAAA }\end{array}$ & $\begin{array}{l}\text { AAAAAAGA } \\
\text { GTTAGCCG } \\
\text { GTGCTTCT }\end{array}$ & $\begin{array}{l}\text { GGAGGAAGGGAGTAAAG } \\
\text { TTAATACCTTTGCTCATTG } \\
\text { ACGTTACCCGCAGAAGA } \\
\text { AGCACCGGCTAACTCC }\end{array}$ & $\begin{array}{l}\text { GGAGGA } \\
\text { AGGGAGT } \\
\text { AAAGTTA } \\
\text { AT }\end{array}$ & $\begin{array}{l}\text { GGAGTTAGC } \\
\text { CGGTGCTTC } \\
\mathrm{T}\end{array}$ \\
\hline $\begin{array}{l}\text { Eberthella } \\
\text { typhi }\end{array}$ & $\begin{array}{l}\text { ACCACAAC } \\
\text { ACCTTCCTC } \\
\text { CAAAAAA }\end{array}$ & $\begin{array}{l}\text { AAAAAAGA } \\
\text { GTTAGCCG } \\
\text { GTGCTTCT }\end{array}$ & $\begin{array}{l}\text { GGAGGAAGGTGTTGTGG } \\
\text { TTAATAACCGCAGCAATT } \\
\text { GACGTTACCCGCAGAAG } \\
\text { AAGCACCGGCTAACTC }\end{array}$ & $\begin{array}{l}\text { GGAGGA } \\
\text { AGGTGTT } \\
\text { GTGGTTA }\end{array}$ & $\begin{array}{l}\text { GAGTTAGCC } \\
\text { GGTGCTTCT } \\
\text { TC }\end{array}$ \\
\hline $\begin{array}{l}\text { Listeria } \\
\text { monocytogen } \\
\text { es }\end{array}$ & $\begin{array}{l}\text { ACTCCAGTC } \\
\text { TTCCAGTTT } \\
\text { CAAAAAA }\end{array}$ & $\begin{array}{l}\text { AAAAAAAC } \\
\text { ATATCTACG } \\
\text { CATTTCA }\end{array}$ & $\begin{array}{l}\text { GGAAACTGGAAGACTGG } \\
\text { AGTGCAGAAGAGGAGAG } \\
\text { TGGAATTCCACGTGTAGC } \\
\text { GGTGAAATGCGTAGATAT } \\
\text { GT }\end{array}$ & $\begin{array}{l}\text { GGAAACT } \\
\text { GGAAGAC } \\
\text { TGGA }\end{array}$ & $\begin{array}{l}\text { ACATATCTAC } \\
\text { GCATTTCA }\end{array}$ \\
\hline $\begin{array}{l}\text { Vibrio } \\
\text { parahaemolyt } \\
\text { icus }\end{array}$ & $\begin{array}{l}\text { CTACTTGGA } \\
\text { GGTTGTGGC } \\
\text { CTAAAAAA }\end{array}$ & $\begin{array}{l}\text { AAAAAAGG } \\
\text { AGCAAACA } \\
\text { GGATTAGAT } \\
\text { A }\end{array}$ & $\begin{array}{l}\text { AGGCCACAACCTCCAAG } \\
\text { TAGACATCGTTTACGGCG } \\
\text { TGGACTACCAGGGTATCT } \\
\text { AATCCTGTTTGCTCC }\end{array}$ & $\begin{array}{l}\text { AGGCCAC } \\
\text { AACCTCC } \\
\text { AAGTAG }\end{array}$ & $\begin{array}{l}\text { GGAGCAAAC } \\
\text { AGGATTAGA } \\
\text { TA }\end{array}$ \\
\hline $\begin{array}{l}\text { Pseudomonas } \\
\text { aeruginosa }\end{array}$ & $\begin{array}{l}\text { AACTTACTG } \\
\text { CCCTTCCTC } \\
\text { CAAAAAA }\end{array}$ & $\begin{array}{l}\text { AAAAAAAC } \\
\text { GAAGTTAG } \\
\text { CCGGTGCT } \\
\text { T }\end{array}$ & $\begin{array}{l}\text { GGAGGAAGGGCAGTAAG } \\
\text { TTAATACCTTGCTGTTTTG } \\
\text { ACGTTACCAACAGAATAA } \\
\text { GCACCGGCTAACTTCGT }\end{array}$ & $\begin{array}{l}\text { GGAGGA } \\
\text { AGGGCAG } \\
\text { TAAGTT }\end{array}$ & $\begin{array}{l}\text { ACGAAGTTA } \\
\text { GCCGGTGCT } \\
\text { TA }\end{array}$ \\
\hline $\begin{array}{l}\text { Streptococcus } \\
\text { pyogenes }\end{array}$ & $\begin{array}{l}\text { CACTCCCAC } \\
\text { CATCATTCT } \\
\text { TCAAAAAA }\end{array}$ & $\begin{array}{l}\text { AAAAAAGT } \\
\text { TAGCCGTC } \\
\text { CCTTTCTG }\end{array}$ & $\begin{array}{l}\text { GAAGAATGATGGTGGGA } \\
\text { GTGGAAAATCCACCAAG } \\
\text { TGACGGTAACTAACCAGA } \\
\text { AAGGGACGGCTAACTA }\end{array}$ & $\begin{array}{l}\text { GAAGAAT } \\
\text { GATGGTG } \\
\text { GGAGTG }\end{array}$ & $\begin{array}{l}\text { TAGTTAGCC } \\
\text { GTCCCTTTC } \\
\text { TG }\end{array}$ \\
\hline $\begin{array}{l}\text { Staphylococc } \\
\text { us aureus }\end{array}$ & $\begin{array}{l}\text { CTTACACAT } \\
\text { ATGTTCTTC } \\
\text { CAAAAAA }\end{array}$ & $\begin{array}{l}\text { AAAAAATA } \\
\text { GTTAGCCG } \\
\text { TGGCTTTCT }\end{array}$ & $\begin{array}{l}\text { GGGAAGAACATATGTGTA } \\
\text { AGTAACTGTGCACATCTT } \\
\text { GACGGTACCTAATCAGAA } \\
\text { AGCCACGGCTAACTAC }\end{array}$ & $\begin{array}{l}\text { GGGAAG } \\
\text { AACATAT } \\
\text { GTGTAAG } \\
\text { TA }\end{array}$ & $\begin{array}{l}\text { GTAGTTAGC } \\
\text { CGTGGCTTT } \\
\text { CT }\end{array}$ \\
\hline $\begin{array}{l}\text { Enterococcus } \\
\text { faecalis }\end{array}$ & $\begin{array}{l}\text { ACTAACGTC } \\
\text { CTTGTTCTT } \\
\text { CAAAAAA }\end{array}$ & $\begin{array}{l}\text { AAAAAATA } \\
\text { GTTAGCCG } \\
\text { TGGCTTTCT }\end{array}$ & $\begin{array}{l}\text { GAAGAACAAGGACGTTA } \\
\text { GTAACTGAACGTCCCCTG } \\
\text { ACGGTATCTAACCAGAAA } \\
\text { GCCACGGCTAACTAC }\end{array}$ & $\begin{array}{l}\text { GAAGAAC } \\
\text { AAGGACG } \\
\text { TTAGTA }\end{array}$ & $\begin{array}{l}\text { GTAGTTAGC } \\
\text { CGTGGCTTT } \\
\text { CT }\end{array}$ \\
\hline $\begin{array}{l}\text { Klebsiella } \\
\text { pneumonia }\end{array}$ & $\begin{array}{l}\text { AAAAAAGA } \\
\text { GGAAGGCG } \\
\text { GTGAGGT }\end{array}$ & $\begin{array}{l}\text { AGAAGCAC } \\
\text { CGGCTAAC } \\
\text { TCCGTAAA } \\
\text { AAA }\end{array}$ & $\begin{array}{l}\text { GGAGGAAGGCGGTGAGG } \\
\text { TTAATAACCTCATCGATTG } \\
\text { ACGTTACCCGCAGAAGA } \\
\text { AGCACCGGCTAACTCCGT }\end{array}$ & $\begin{array}{l}\text { GGAGGA } \\
\text { AGGCGGT } \\
\text { GAGGT }\end{array}$ & $\begin{array}{l}\text { ACGGAGTTA } \\
\text { GCCGGTGCT } \\
\text { TCT }\end{array}$ \\
\hline $\begin{array}{l}\text { Proteus } \\
\text { mirabilis }\end{array}$ & $\begin{array}{l}\text { TAACCTTAT } \\
\text { CACCTTCCT } \\
\text { CAAAAAA }\end{array}$ & $\begin{array}{l}\text { AAAAAAGA } \\
\text { GTTAGCCG } \\
\text { GTGCTTCT }\end{array}$ & $\begin{array}{l}\text { GGAGGAAGGTGATAAGG } \\
\text { TTAATACCCTTNTCAATTG } \\
\text { ACGTTACCCGCAGAAGA } \\
\text { AGCACCGGCTAACTCC }\end{array}$ & $\begin{array}{l}\text { GGAGGA } \\
\text { AGGTGAT } \\
\text { AAGGTTA } \\
\text { A }\end{array}$ & $\begin{array}{l}\text { GGAGTTAGC } \\
\text { CGGTGCTTC } \\
\mathrm{T}\end{array}$ \\
\hline
\end{tabular}


2. GBP-trypsin and proaerolysin expression and purification.

\subsection{Analysis of cloning of pchia transformants}
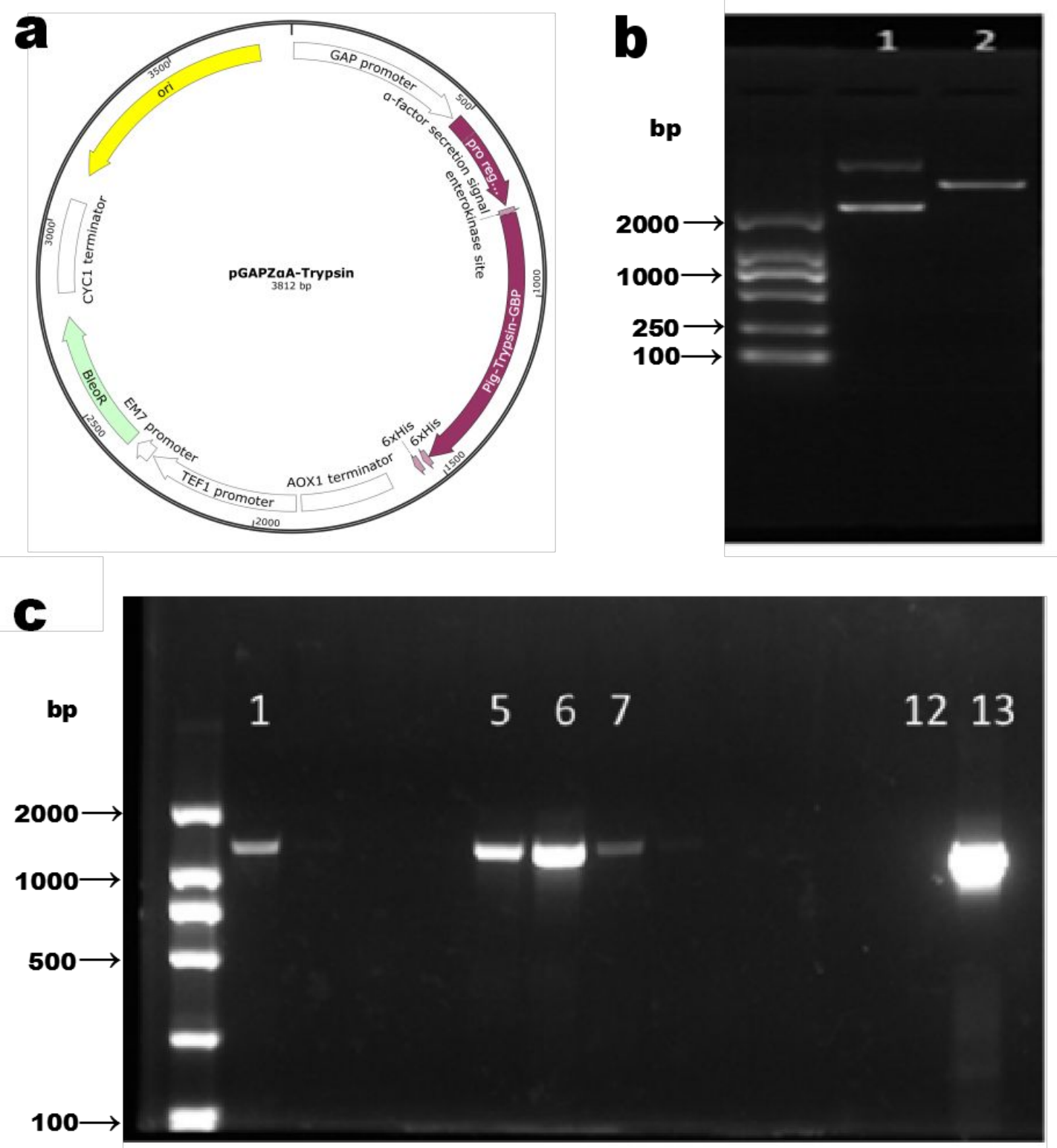

Figure $\mathbf{S 1}$ Characterization of pGAPZa A-trypsinogen plasmid. Scheme of pGAPZa A-trypsinogen plasmid (a). Detection (b) of linearized plasmid (pGAPZa A-trypsinogen) without (1) and with (2) BspHI enzyme; Analysis (c) of pichia transformants for pGAPZ $\alpha$ A-trypsinogen positive cloning $(1,5,6$, and 7 ), blank sample (12), and the control positive sample (13). 


\subsection{The GBP-labeled trypsinogen preparation and its activities.}

a
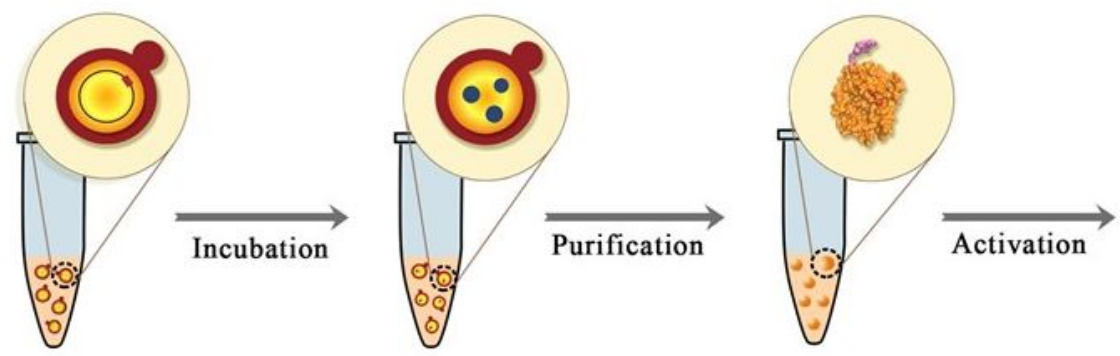

Transformed Yeast

Expressed Yeast

GBP-trypsinogen

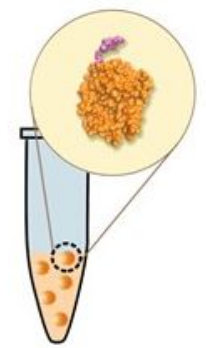

GBP-trypsin

b $\quad$ KD
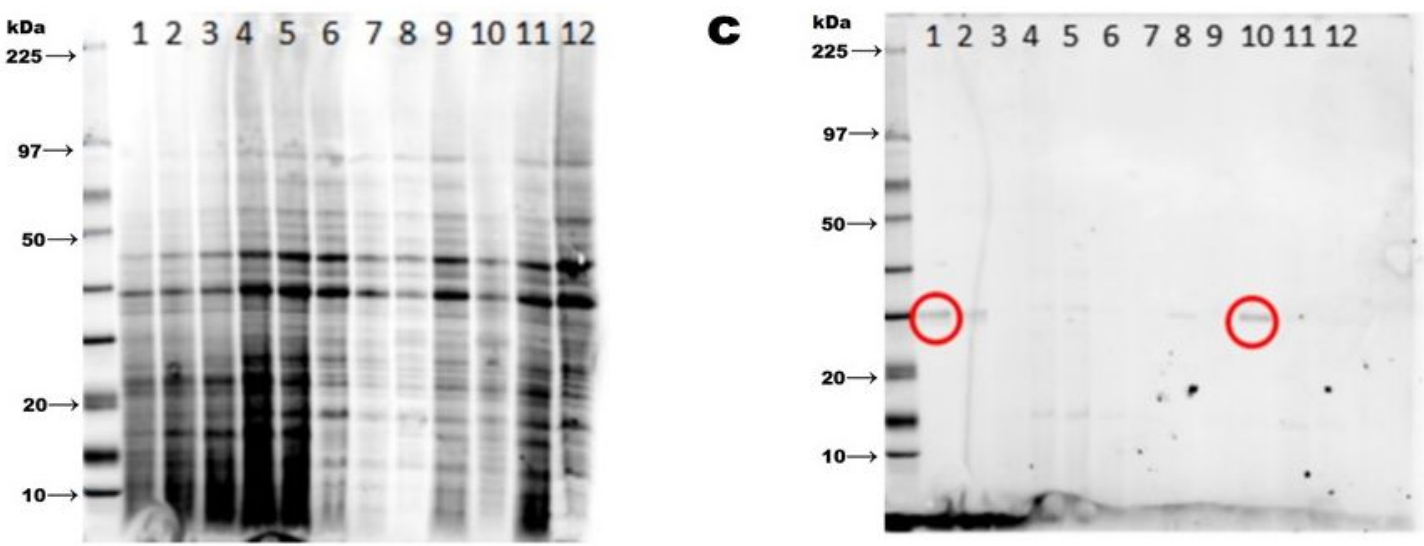

Figure S2 GBP-labeled trypsinogen preparation using yeast expressing system (a). Optimization of GBP-labeled trypsinogen confirmed by western blotting detection ( $b$ and $c$ ).Transformed Pichia pastoris GS115 (CICC) using Gene Pulser Xcell (Bio-Rad Laborataries, Inc) was incubated at $37^{\circ} \mathrm{C}$ in YPD medium with shaking at 150 rpm for 36 (1), 48 (2), 72 (3), 96 (4), 120 (5), 168 (6), and 192 (7) h of protocol 1; 36 (8) and 120 (9) h of protocol 2; 36 (10) and 120 (11) h of protocol 3, and blank control (12). 

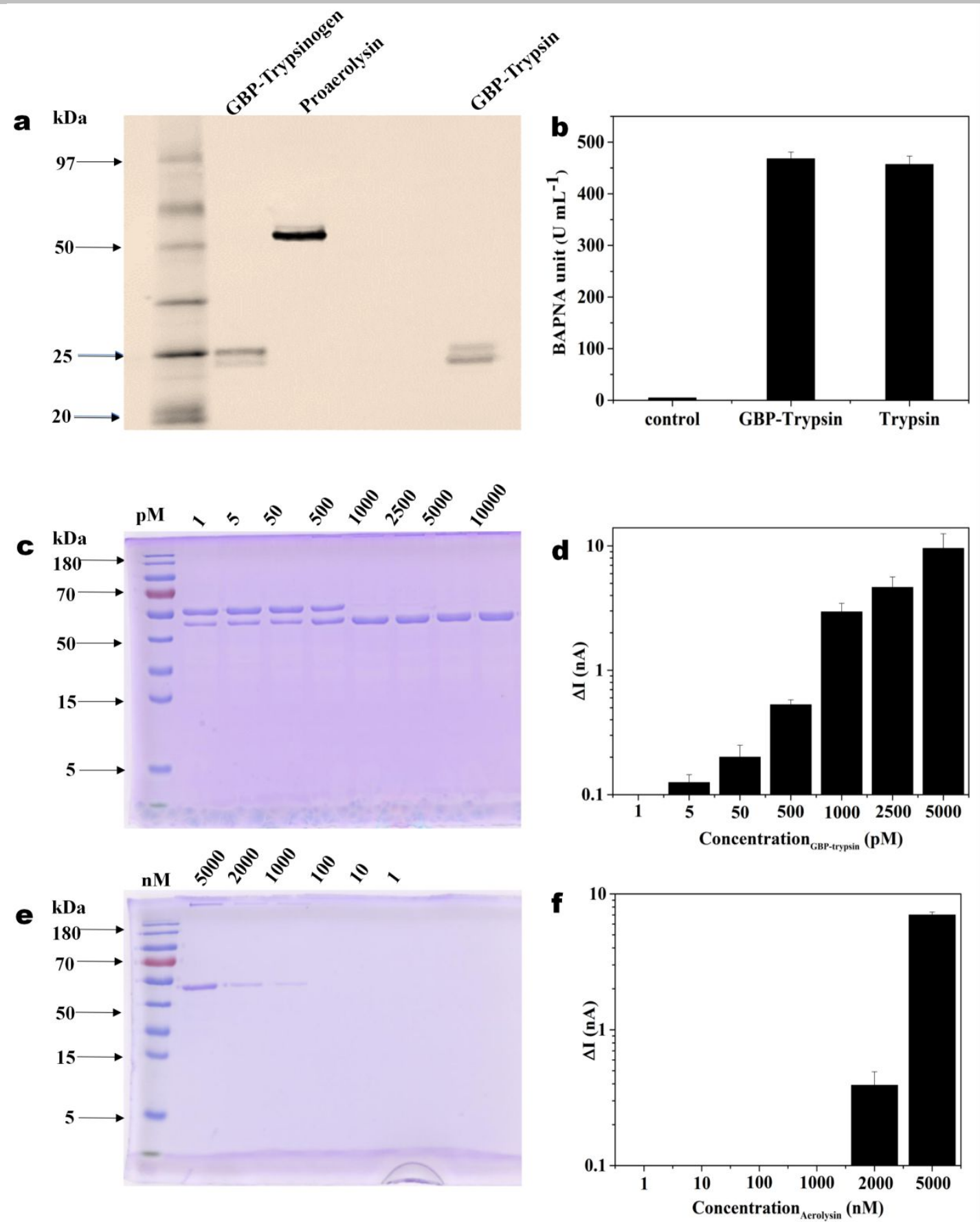

Figure S3. Engineered trypsin produce ultrasensitive electrical response. The electrical signal reporter, proaerolysin, is activated by proteolytic cleavage of trypsin produced from yeast expressing system in the complex. The activated aerolysin inserts into the lipid bilayer and generates response current. (a) Western blotting detection of purified proteins, such as GBP-trypsinogen, proaerolysin and GBP-trypsin. (b) BAPNA detection of GBP-trypsin activity for the control sample, purchased trypsin, and purified trypsin using yeast expressing system. Activation of electrical signal reporter, proaerolysin, using different concentration of GBP-trypsin (c) and different concentration of aerolysin (e) confirmed by SDS-PAGE. The current intensity of different concentrations of GBP-trypsin for activation of proaerolysin from $1 \mathrm{pM}$ to $10 \mathrm{nM}(\mathrm{d})$ and different concentrations of aerolysin from $1 \mathrm{nM}$ to $5000 \mathrm{nM}(\mathrm{f})$ using eONE nanopore sensing platform. 
3 Characterization of probes and tNASA nanocomplexes
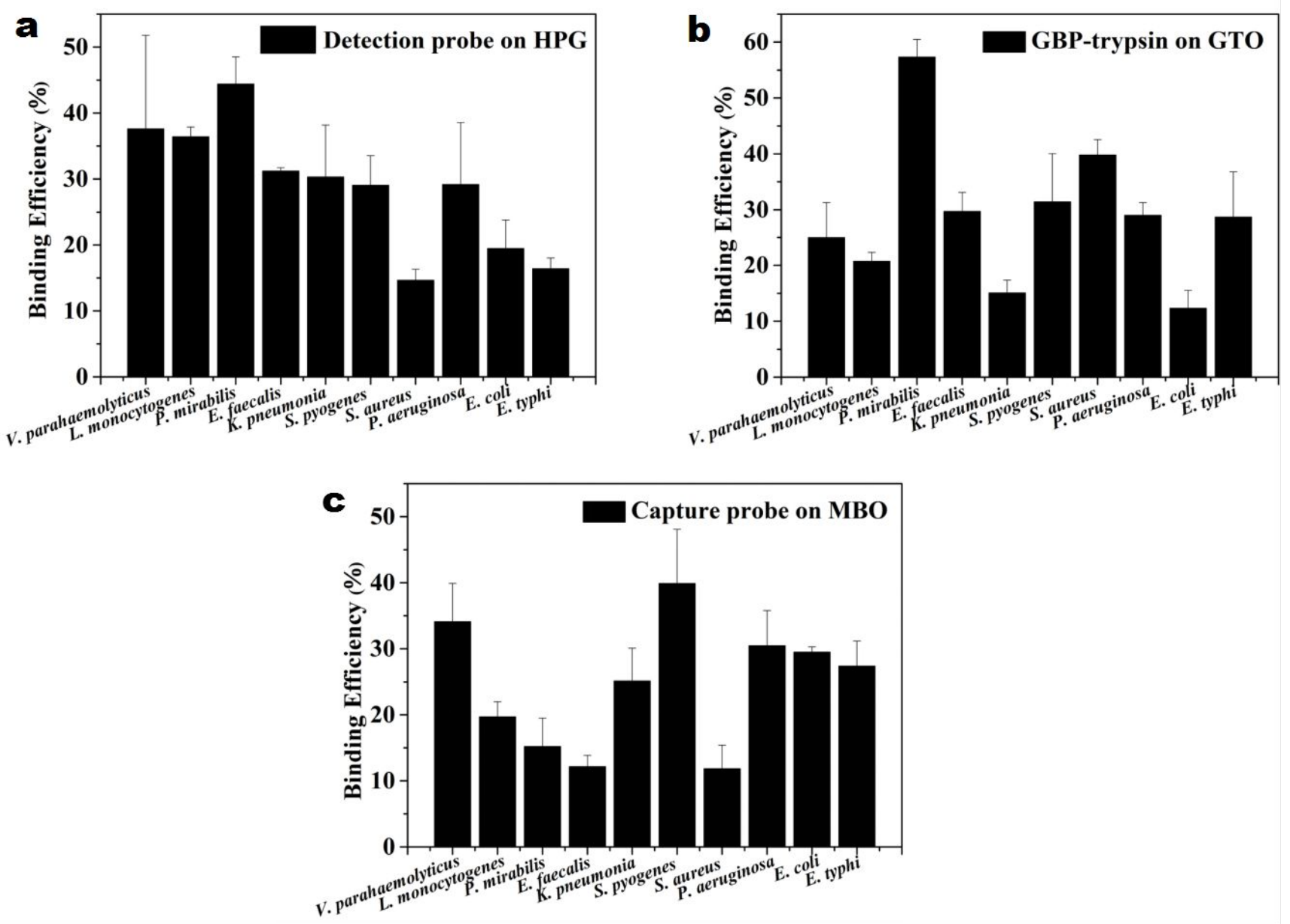

Figure S4. Binding efficiency of detection probes (a) and GBP-tagged trypsin (b) conjugated onto GTO probe and capture probe (c) onto MBO probe. The bind efficiency of probe and GBP-tagged trypsin conjugated onto GTO probe and MBO probe is expressed as: $\left(F_{\text {sample }}-F_{\text {supernatant }}\right) / F_{\text {sample }} \times 100 \%$. Where $F_{\text {sample }}$ is fluorescent of initial DNA probe or GBP-tagged trypsin with dye, and $F_{\text {supernatant }}$ is fluorescent of DNA probe or GBP-tagged trypsin with dye after specific binding in supernatant. 

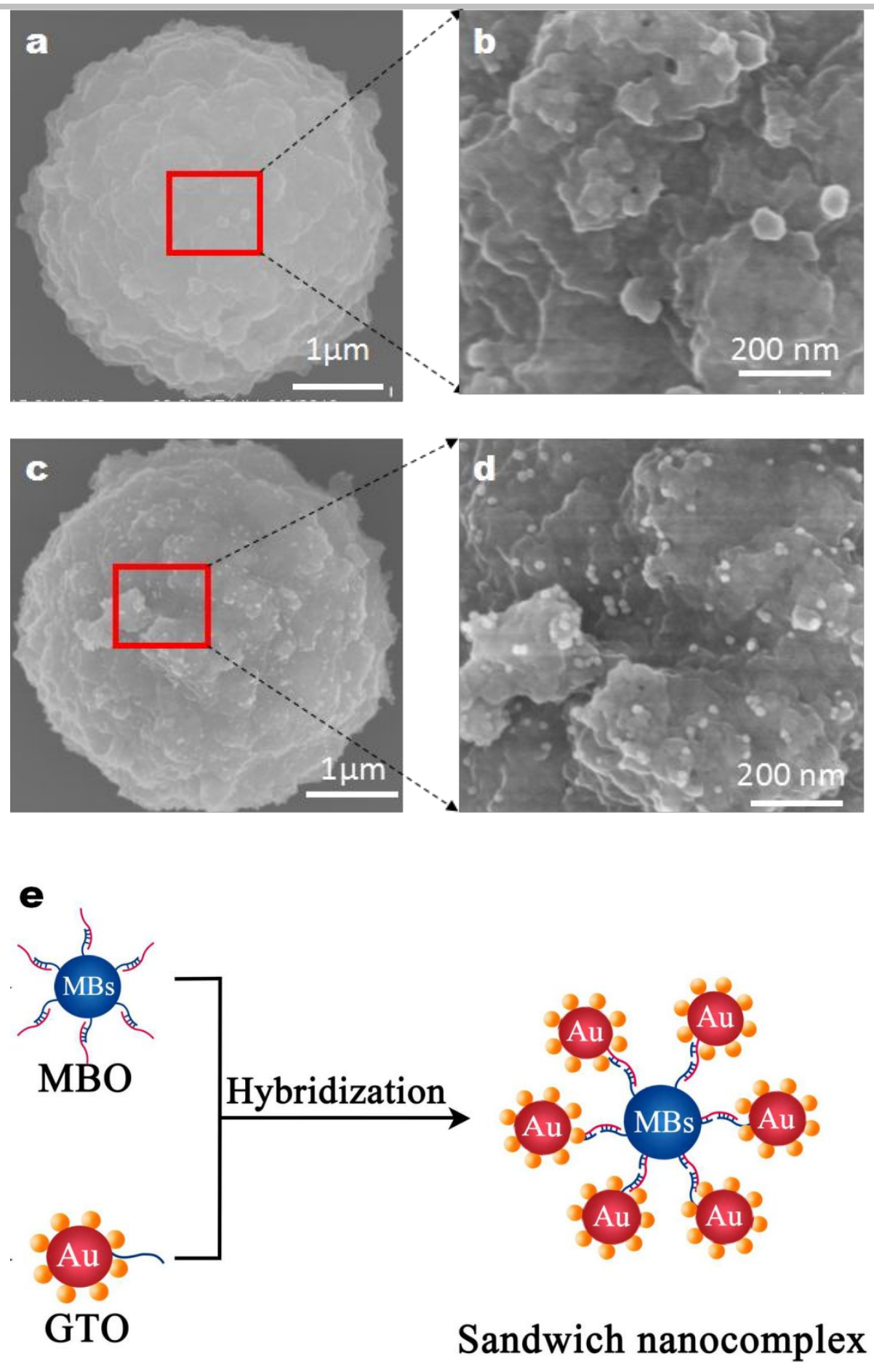

Figure S5. tNASA complexes using scanning electron microscopy (SEM). SEM image confirms the formation of sandwich complex between MBO and GTO probes in the absence ( $a$ and $b$ ) and presence (c and d) of target (e). The solution containing $40 \mu \mathrm{l}$ of 2-functionalized MBO probes at $2.0 \mathrm{mg} / \mathrm{mL}, 40$ $\mu \mathrm{l}$ of GTO at $2.0 \mathrm{nM}, 20 \mu \mathrm{l}$ of buffer with bacteria DNA target, $S$. aureus. All of the above reaction tubes were gently shaken for 1 hour at room temperature in an incubator before placed on the magnetic stand. 


\section{Detection DNA and bacteria with tNASA method (specificity and sensitivity)}
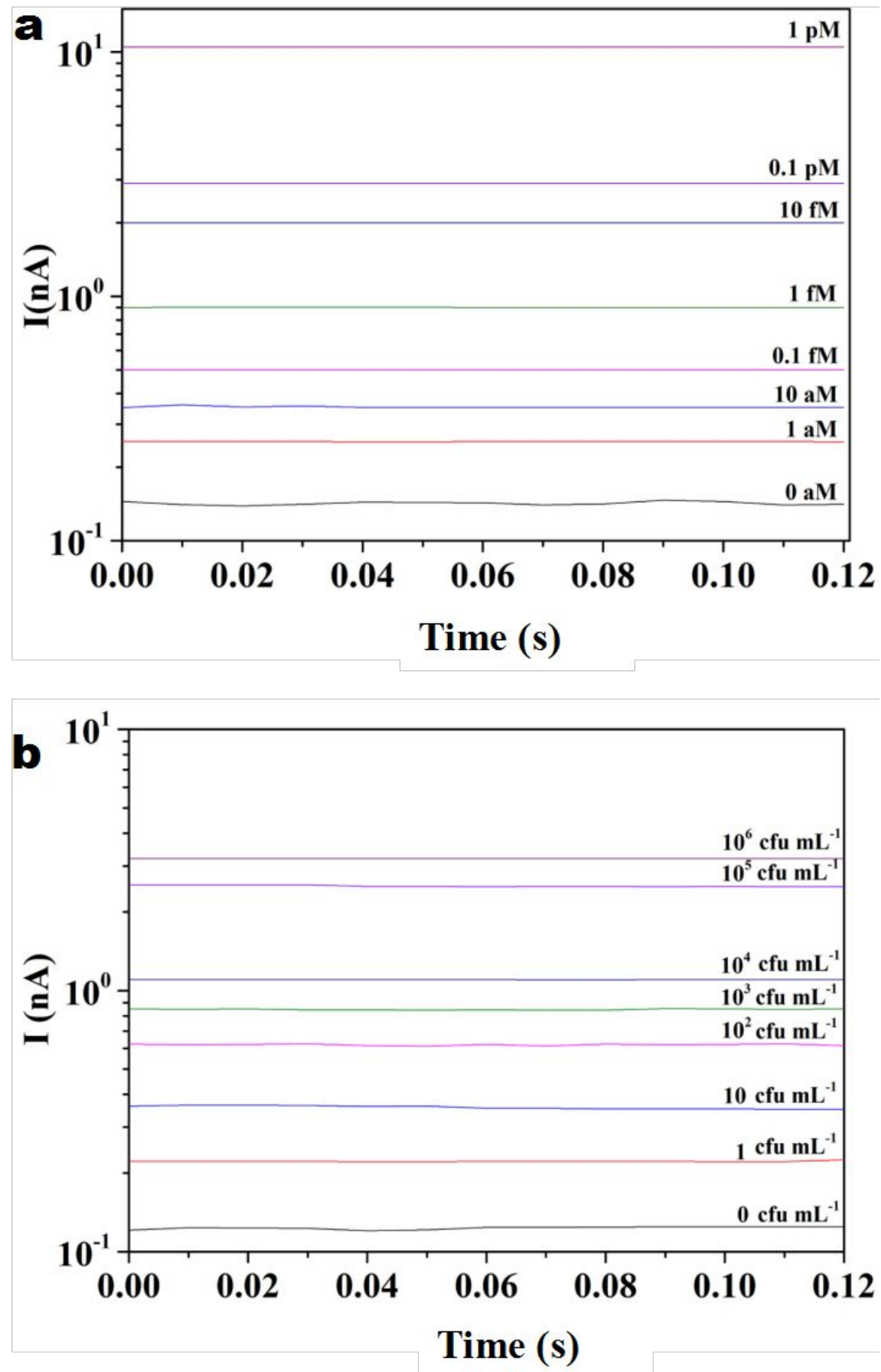

Figure S6 DNA detection from E. coli ranged from 1 aM to $1 \mathrm{pM} \mathrm{(a)} \mathrm{and} \mathrm{Bacterial} \mathrm{detection} \mathrm{(E.} \mathrm{coli)}$ ranged from 0 to $10^{6} \mathrm{cfu} \mathrm{mL}^{-1}$ (b) by tNASA. For nanopore current measurement using miniaturized one-channel amplifier, a positive potential $(+100 \mathrm{mV})$ was applied and $12 \mu \mathrm{l}$ of the supernatant containing the released GBP-labeled hemolysin from the nanocomplexes in the electrolyte solutions (1.0 M KCl, $10 \mathrm{mM}$ Tris and $1.0 \mathrm{mM}$ EDTA, $\mathrm{pH}$ 8.0). 


\section{Detection bacteria and clinic diagnostic with qPCR method}
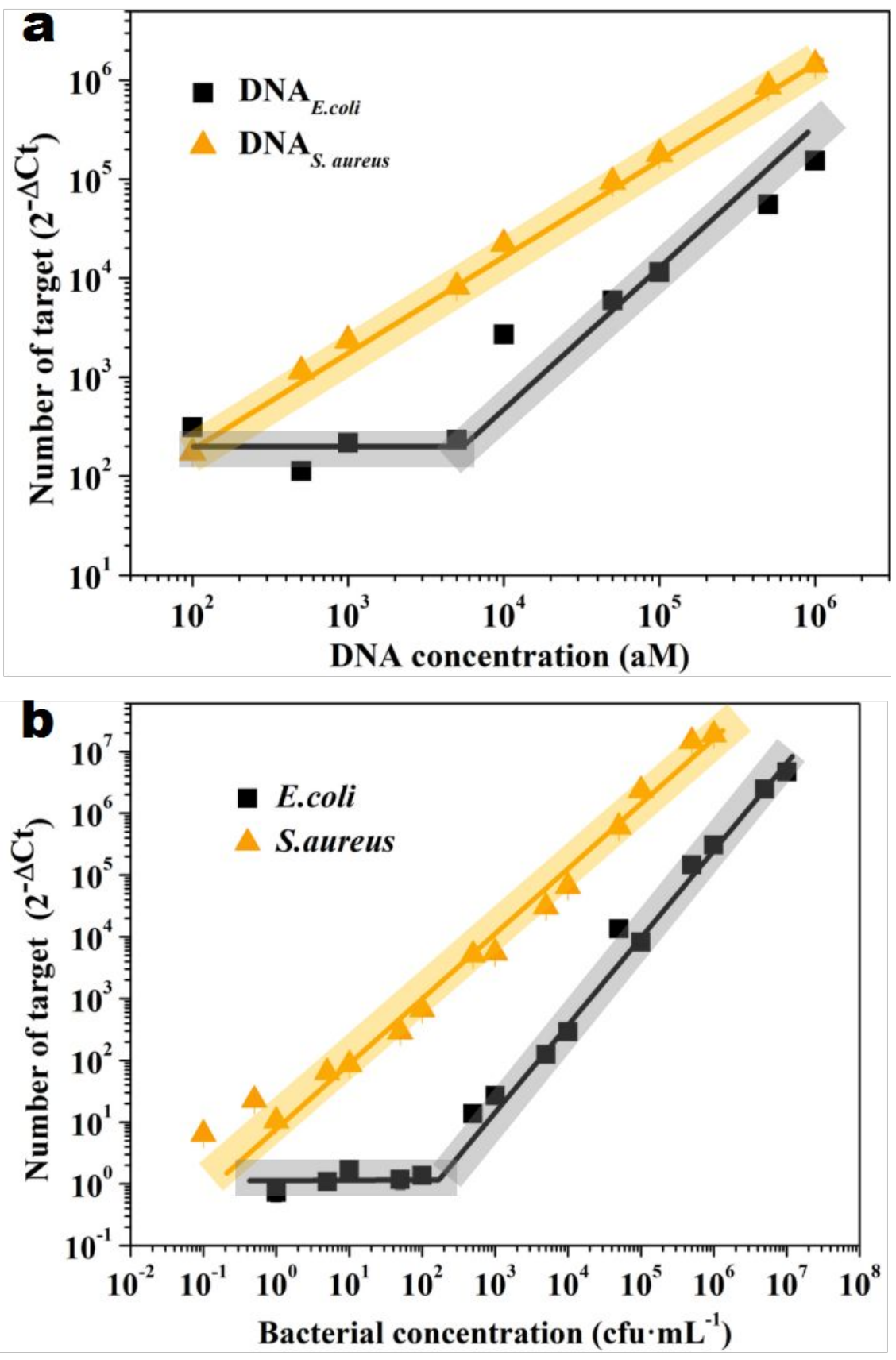

Figure S7 DNA detection (a) and bacterial detection (b) by qPCR system. Serial dilutions of bacteriaderived DNA were used as detection targets. Bacteria-derived DNA molecules were obtained via asymmetric RT-PCR of $S$. aureus and $E$. coli $16 S$ rRNA. Synthetic DNA had the same sequence as bacteria-derived DNA. The detection limit was $1 \mathrm{aM}$. Samples with varying numbers of $S$. aureus and $E$. coli were used. Amplified target DNA were detected using the probe set in Table S1. The observed detection limit was a single bacterium. 


\section{Bacteria RNA extraction and amplification}

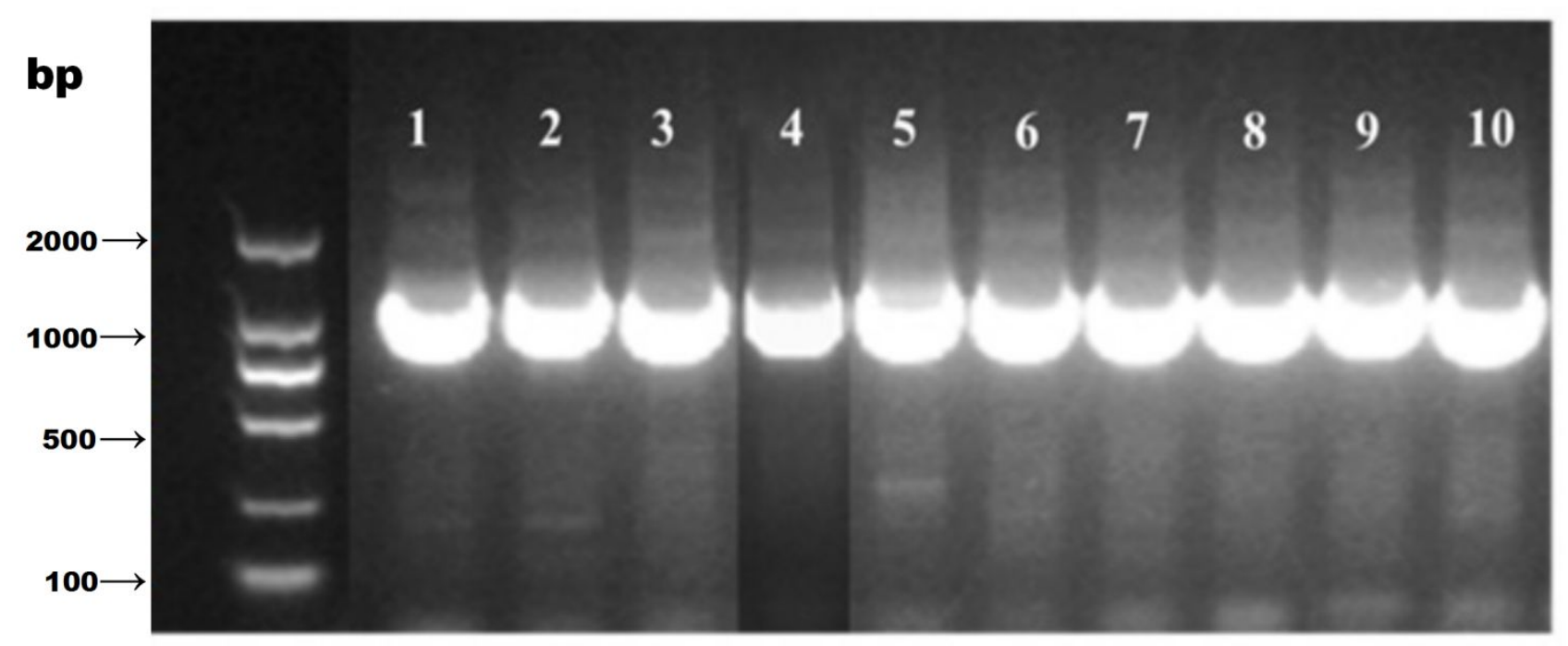

Figure S8 Bacteria RNA extraction and amplification. Amplification of Bacterial derived RNA from ten different segments (a). [Vibrio parahaemolyticus (1), Listeria monocytogenes (2), Proteus mirabilis (3), Enterococcus faecalis (4), Klebsiella pneumonia (5), Streptococcus pyogenes (6), Staphylococcus aureus (7), Pseudomonas aeruginosa (8), Escherichia coli (9), and Eberthella typhi (10)]. 
7. Detection bacteria and clinic diagnostic with QPCR and culture method

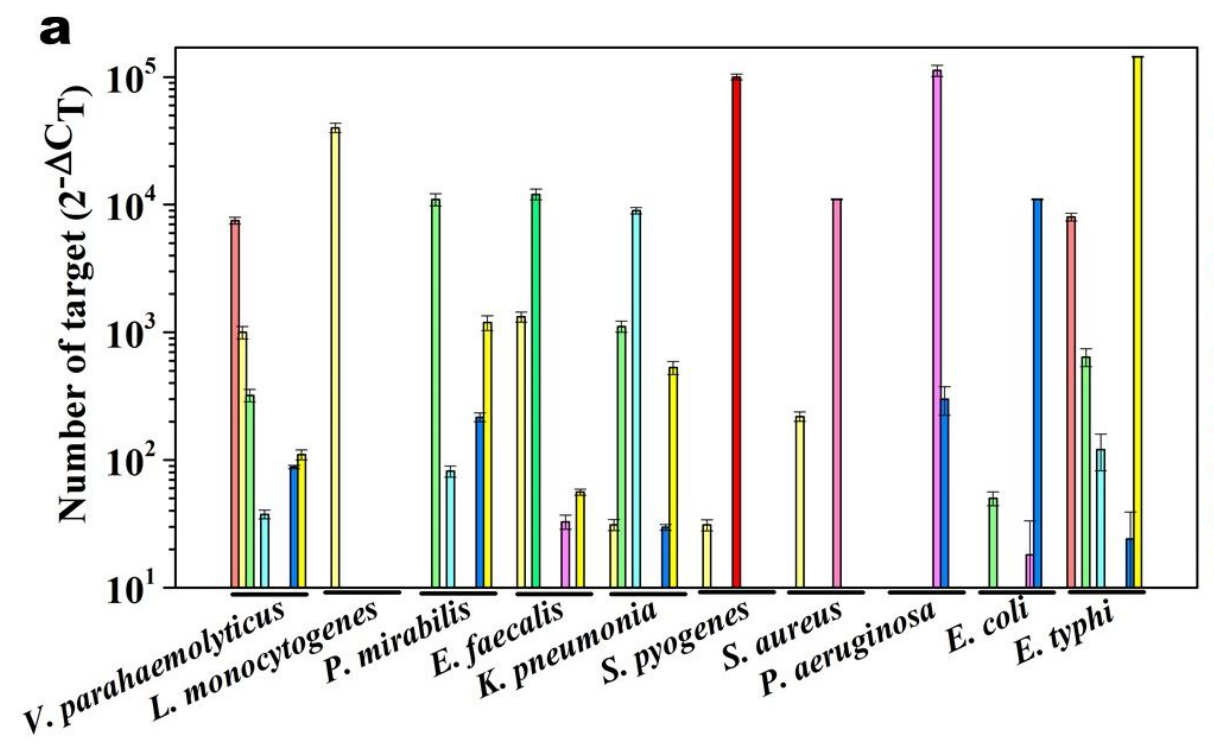

$\square$ Vibrio

$\square$ Listeria

$\square$ Proteus

$\square$ Enterococcus

$\square$ Klebsiella

Streptococcus

Staphylococcus

$\square$ Pseudomonas

Escherichia

Eberthella

b

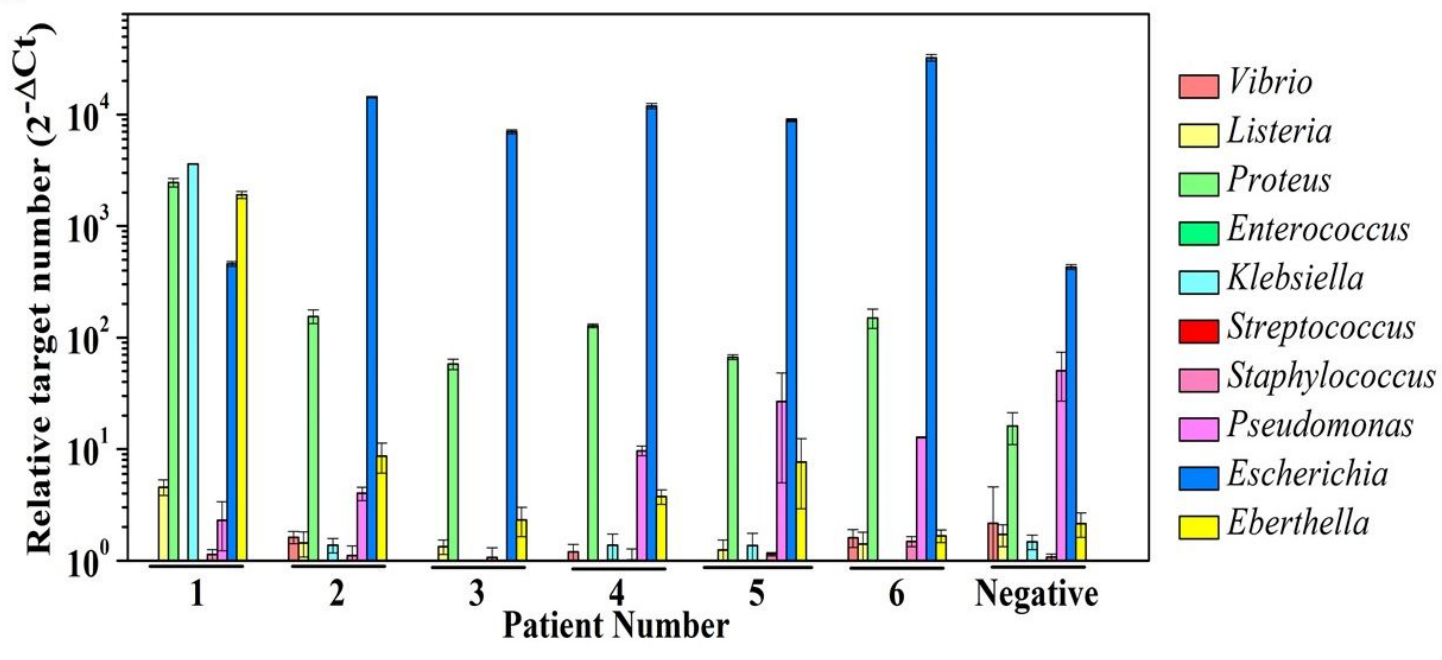

Figure S9 Differential detection (a) and clinical diagnostic (b) using qPCR. The products amplified from bacteria were hybridized with detection probe and capture probe. Probes targeting hypervariable regions of bacterial 16S rRNA sequences were used to specifically detect various bacterial types using qPCR. Probes specific for different bacteria were utilized for detecting various bacterial types $\left(10^{5} \mathrm{cfu} \mathrm{mL}^{-1}\right)$. Detection of bacteria by qPCR using specific probes for each bacteria type in clinical samples. Clinical specimens were processed. One of the seven clinical specimens was negative, which confirmed with standard culture method. The last samples were negative. Results are shown as mean + s.d. All specimens for the tests were measured in triplicate. 
Table S2. Comparison of different techniques, such as tNASA, qPCR, and culture, for bacterial detection in clinical samples.

\begin{tabular}{llll}
\hline $\begin{array}{l}\text { Patient } \\
\text { Number }\end{array}$ & tNASA $^{\text {a }}$ & qPCR & Bacterial culture $^{\text {c }}$ \\
\hline 1 & $\begin{array}{l}\text { K. pneumonia } \\
(4.0 \pm 0.9)\end{array}$ & K. pneumonia $\left(3.6 \pm 0.1 \times 10^{3}\right)$ & None $^{\text {d }}$ \\
& & P. Mirabilis $\left(2.4 \pm 0.2 \times 10^{3}\right)$ & \\
& & E. coli $\left(4.3 \pm 0.3 \times 10^{2}\right)$ & \\
2 & E. Typhi $\left(1.9 \pm 0.5 \times 10^{3}\right)$ & \\
3 & E. coli $(2.3 \pm 0.3)$ & E. coli $\left(6.9 \pm 0.1 \times 10^{5}\right)$ & E. coli $(++)$ \\
4 & E. coli $(2.1 \pm 0.2)$ & E. coli $\left(1.2 \pm 0.2 \times 10^{4}\right)$ & E. coli $(++)$ \\
5 & E. coli $(2.7 \pm 0.4)$ & E. coli $\left(8.9 \pm 0.4 \times 10^{3}\right)$ & E. coli $(++)$ \\
6 & E. coli $(3.1 \pm 0.5)$ & E. coli $\left(3.2 \pm 0.3 \times 10^{4}\right)$ & E. coli $(+++)$ \\
Negative & None & E. coli $\left(4.5 \pm 0.5 \times 10^{2}\right)$ & None
\end{tabular}

aValues for tNASA assay represent $\Delta \mathrm{l}$ values. Higher $\Delta \mathrm{I}$ values indicate higher bacterial abundance; bValues for qPCR assay represent $2^{-\Delta C t}$ values. Higher $2^{-\Delta C t}$ values indicate higher bacterial abundance; 'Detection levels of culture method using Biolumix: high level (more than 10,000 $\mathrm{cfu} \mathrm{mL}^{-1}$ ) for +++ , moderate level $\left(1,000-10,000 \mathrm{cfu} \mathrm{mL}^{-1}\right)$ for ++ , and low concentration (less than $100 \mathrm{cfu} \mathrm{mL}^{-1}$ ) for + . ${ }^{\mathrm{d}}$ The results of $K$. pneumonia cannot be detected using bacterial culture and show a false negative. 
Table S3. Comparison of different techniques, such as a magneto-DNA nanoparticle system (Magneto-DNA), quantitative polymerase chain reaction (qPCR), culture, and trypsin-activated nanopore amplified sandwich assay (tNASA), for bacterial detection.

\begin{tabular}{|c|c|c|c|c|}
\hline & $\begin{array}{l}\text { Magneto- } \\
\text { DNA }^{(2)}\end{array}$ & qPCR & Culture & tNASA \\
\hline $\begin{array}{l}\text { Procedure } \\
\text { time }\end{array}$ & $<2$ hours & $<2$ hours & $2-10$ days & 3 hours \\
\hline Sensitivity & $\begin{array}{l}0.5 \mathrm{pM} \text { for } \\
\text { DNA; } \\
1 \text { CFU for } \\
\text { bacteria }\end{array}$ & $\begin{array}{c}1 \mathrm{fM} \text { for DNA; } \\
1 \mathrm{CFU} \text { for } \\
\text { bacteria }\end{array}$ & $\begin{array}{l}1 \text { CFU for } \\
\text { bacteria }\end{array}$ & $\begin{array}{c}\text { 1aM for DNA; } \\
1 \mathrm{CFU} \text { for bacteria }\end{array}$ \\
\hline False positive & NO & YES & Yes & NO \\
\hline $\begin{array}{l}\text { Cost per } \\
\text { assay }\end{array}$ & $\begin{array}{c}\sim \$ 1 \\
\text { (magnetic } \\
\text { nanoparticles, } \\
\text { beads, } \\
\text { probes, } \\
\text { polymerase, } \\
\text { primers) }\end{array}$ & $\begin{array}{c}\sim \$ 1 \\
\text { (enzymes, } \\
\text { fluorescent } \\
\text { dyes, primers) }\end{array}$ & $\begin{array}{c}\text { \$0.1 (media } \\
\text { incubation } \\
\text { plates) }\end{array}$ & $\begin{array}{c}\sim \$ 1 \text { (magnetic } \\
\text { nanoparticles, gold } \\
\text { nanoparticles, } \\
\text { probes, } \\
\text { polymerase, } \\
\text { primers, GBP- } \\
\text { tagged trypsin, } \\
\text { proaerolysin) }\end{array}$ \\
\hline Time & $1-2 \mathrm{hrs}$ & $1-2 \mathrm{hrs}$ & $12-24 \mathrm{hrs}$ & $2 \mathrm{hrs}$ \\
\hline POC & YES & NO & NO & YES \\
\hline Application & & & & \\
\hline
\end{tabular}

\section{References}

(1) D. Zhang, J. W. Pridgeon, P. H. Klesius, Vet Microbiol 2013, 165, 478-482.

(2) H. J. Chung, C. M. Castro, H. Im, H. Lee, R. Weissleder, Nat Nanotechnol 2013, 8, 369-375. 